$47, \mathrm{XX},+\mathrm{G}(8 \%) .{ }^{5}$ This low percentage mosaic state for a small acrocentric chromosome was probably coincidental. A karyotype of 46,XX,r(18)(p11q23), also probably an unrelated finding, was found in a third infant with lethal OI. ${ }^{6}$ Finally, a child with less severe disease had a karyotype of $46, \mathrm{XY}$, del(12) (p12p13). His father, who had a normal karyotype, also had moderately severe OI, indicating that OI in the child was probably unrelated to the partial deletion. ${ }^{7}$ We know of no previous report of OI associated with karyotypic abnormalities involving type I collagen gene sites.

Damage to one $\alpha 2$ (I) procollagen allele caused by the inversion might have contributed to disease in the infant if a mutation affecting the other allele was present. Such a mutation might either have occurred de novo or have been inherited from the father; compound heterozygosity for abnormalities in the $\alpha 2(I)$ procollagen gene, one of which was phenotypically recessive, has previously been reported in lethal 'broad boned' OI. ${ }^{8}$ It is also possible that a different de novo mutation caused OI in the infant by affecting one $\alpha 1$ (I) procollagen allele ${ }^{9}$ and that the observed inversion was not related to his disease. The risk that other children born to these parents will have OI is increased only if each parent is heterozygous for an $\alpha 2(\mathrm{I})$ procollagen gene abnormality. Attempts are now in progress to characterise $\alpha 2(\mathrm{I})$ procollagen genes and gene products in the parents for purposes of genetic counselling.

\section{References}

1 Schulz DM, Giordano DA, Schulz DH. Weights of organs of fetuses and infants. Arch Pathol 1962;74:244-50.

2 Auf'mholk B, Schwartz ER. Biochemical characterizations of human osteoblasts in culture. In: Dixon DA, Sarnat BG, eds. Normal and abnormal bone growth: basic and clinical research. New York: Alan R Liss, 1985: 210-4.

${ }^{3}$ McAlpine PJ, Shows TB, Miller RL, Pakstis AJ. The 1985 catalog of mapped genes and report of the nomenclature committee. HGM8. Cytogenet Cell Genet 1985;40:8-66.

${ }^{4}$ Richon J, Brunel G, Gilbenkrantz A, Masson JM. À propos d'un cas de fragilité tissulaire généralisée avec caryotype inédit chez un enfant mort au cours d'une extraction spectaculaire. Bull Fed Soc Gynecol Obstet Lang Fr 1971;23:503-5.

5 Ninatti GP, Patriarca PL. L'osteogenesi imperfetta (forma precoce di Vroelik). Osservazione clinica di un caso con studio biochemico e genetico. Minerva Pediatr 1968;20:1543-54.

${ }^{6}$ Marković S, Adžić S, Mijin K, Radojković Z, Lopičić L. Prstenasti khromosom $18 \mathrm{i}$ osteogenesis imperfecta u porodižhi u kojoj se javljaju spontani pobačaji. Srp Arh Celok Lek 1979;107:245-52.

7 Orye E, Craen M. Short arm deletion of chromosome 12. Report of two new cases. Humangenetik 1975;28:335-42.

${ }^{8}$ de Wet WJ, Pihlajaniemi T, Myers J, Kelly TE, Prockop DJ. Synthesis of a shortened pro- $\alpha 2$ (I) chain and decreased synthesis of pro- $\alpha 2(\mathrm{I})$ chains in a proband with osteogenesis imperfecta. $J$ Biol Chem 1983;258:7721-8.

${ }^{9}$ Chu M-L, Williams CJ, Pepe G, Hirsch JL, Prockop DJ, Ramirez F. Internal deletion in a collagen gene in a perinatal lethal form of osteogenesis imperfecta. Nature 1983;304:78-80.

Correspondence and requests for reprints to Dr A S Knisely, Department of Pathology and Laboratory Medicine, Women \& Infants' Hospital of Rhode Island, 101 Dudley Street, Providence, Rhode Island 02905-2401, USA.

\title{
Absence of a vagina and right sided adnexa uteri in the Waardenburg syndrome: a possible clue to the embryological defect
}

\author{
R M GOODMAN*, G OELSNER†, M BERKENSTADT*, AND D ADMON $\dagger$ \\ Departments of Medical Genetics* and Obstetrics and Gynecologyt, Chaim Sheba Medical Center, \\ Tel-Hashomer, and The Sackler School of Medicine, Tel-Aviv University, Ramat-Aviv, Israel.
}

SUMMARY An 18 year old single Jewish woman with the Waardenburg syndrome and absence of a vagina and right sided adnexa uteri is reported. Other congenital malformations associated with the Waardenburg syndrome are mentioned and it is postulated that they may be the result of an altered invasion of neurones or altered neurones in certain organ systems early in embryogenesis.
Over the years our group has described various congenital malformations associated with the Waardenburg syndrome. ${ }^{1-4}$ Recently, we had the opportunity to re-evaluate one of our patients that we had seen many years ago, and to our surprise we learned that she was born without a vagina and right adnexa uteri. The purpose of this brief report is to discuss the above observations in relation to other hypoplastic or aplastic congenital malformations seen in the Waardenburg syndrome.

\section{Case report}

An 18 year old single Jewish woman was referred to 


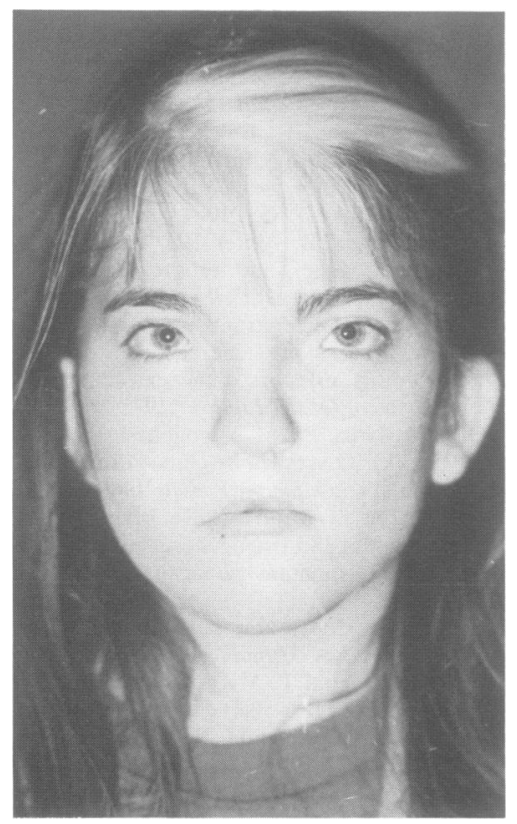

FIGURE The proband showing the characteristic facial features in Waardenburg syndrome plus a white forelock.

our genetic clinic with the diagnosis of the Waardenburg syndrome and absence of a vagina. In going through our records we noted that this woman had been seen in our clinic some seven years ago during a survey of Waardenburg syndrome in Israel. No mention was made of any abnormal genital problems at that time.

The patient has a four generation family history of this disorder with several affected members. To the best of our knowledge no other affected female is known to have absence of the vagina. She received the Waardenburg gene from her affected father. She has all the classical features of this disorder including iris heterochromia, dystopia canthorum, broad nasal bridge, hypoplastic alae, cupid bow upper lip, full lower lip, and prominent mandible. In addition she has a white forelock and usually wears a hearing aid for severe bilateral congenital deafness (figure). At birth a low imperforate anus was noted and this was treated surgically.

At the age of 16 years she consulted a gynaecologist because menarche had not occurred. Examination at that time showed that her secondary sexual characteristics, breasts, and pubic hair were well developed. Pelvic examination showed normal external genitalia with a well developed vulva and a normal sized clitoris. The vagina was absent. The uterus was not palpated but on the left sides? an immobile 5 to $6 \mathrm{~cm}$ mass was palpated. She therg underwent diagnostic laparoscopy and a 7 to 8 weelo size uterus was noted and diagnosed as a haema $\frac{\bar{s}}{\zeta}$ tometra. On the left side a normal ovary and oviduc $\mathbb{B}$ were observed while no adnexa uteri were seen on the right side. An IVP showed a normal right kidney and an ectopic left kidney.

At the age of 17 years she was operated upon and a neovagina was formed and covered by a transfer of a skin graft from her inner left thigh. The neovagina was 2 to $3 \mathrm{~cm}$ wide and 5 to $6 \mathrm{~cm}$ deep. Since theff she has been using moulds to maintain patency ot the vagina. At the age of 18 years she was referredr to the gynaecological clinic of the Sheba Medicau Center for anastomosis of the neovagina with he 5 uterus. Pelvic examination showed a vagina of $6 \mathrm{cmp}$ in depth. Bimanual examination revealed a norma 5 sized uterus, with no masses in the left adnexa an no palpable right adnexa. All her secondary sexuaf features were normal.

\section{Discussion}

The first major congenital malformation shown tơ be definitely associated with the Waardenburg syndrome was aganglionic megacolon (Hirschsprung disease). ${ }^{5}$ Later atretic gastrointestinal anomalies $\stackrel{3}{\rightarrow}$ such as oesophageal atresia, anal atresia, an£ combined atretic lesions with or without tracheo oesophageal fistula were described. ${ }^{4}$

It is of interest that in 1947 when Klein ${ }^{6}$ reported his case, now referred to as Klein-Waardenburg type III disorder, his patient had severe hypoplastic development of the shoulders and upper extremi ties. Since this original report other cases have alsio been described with identical findings. ${ }^{12}$ In 198 은 we concluded, as others had, that the facial ${ }_{6}$ pigmentary, hearing loss, and aganglionic megaco lon findings in the Waardenburg syndrome could b explained by some basic defect in neural crest ce development or migration or both. ${ }^{1}$

Essentially all of the previously mentioned conrs genital malformations of the gastrointestinal traci and the musculoskeletal system, known or thoughf to be associated with the Waardenburg syndrome of one of its variants, are of an aplastic or hypoplastie nature. Thus, we think that the finding in ou, proband of absence of a vagina and one sided adnexa uteri is integrally related to the basic defects in this syndrome. It should be mentioned that th incidence of absence of the vagina is not known anf estimates vary greatly. A group from the May $\odot$ Clinic observed one case in every 4000 female patients. ${ }^{7}$ 
In conclusion, we would like to postulate further that an altered invasion of neurones (of neural crest origin) in certain organ systems may in some way influence the embryological development of a given organ. We fully realise the speculative nature of the above comments and, until similar observations are made by others, all remains theoretical.

This work was supported in part by grants to $R \mathbf{M}$ Goodman from the National Foundation for Jewish Genetic Diseases and LA-CO Industries Inc of the USA, and the Henry Goldberg Memorial Fund in Israel.

\section{References}

1 Goodman RM, Lewithal I, Solomon A, Klein D. A survey of the Klein-Waardenburg syndrome in Israel with emphasis on upper extremity involvement. Evidence for further genetic heterogeneity-type III. In: Huber A, Klein D, eds. Neurogenetics and neuro-ophthalmology. Amsterdam: Elsevier/NorthHolland Biomedical Press, 1981:393-406.
${ }^{2}$ Goodman RM, Lewithal I, Solomon A, Klein D. Upper limb involvement in the Klein Waardenburg syndrome. Am J Med Genet 1982;11:425-33.

${ }^{3}$ Nutman J, Nissenkorn I, Varsana I, Mimouni M, Goodman RM. Anal atresia and the Klein-Waardenburg syndrome. J Med Genet 1981;18:239-41.

${ }^{4}$ Nutman J, Steinherz R, Sivan Y, Goodman RM. Possible Waardenburg syndrome with gastrointestinal anomalies. J Med Genet 1986;23:175-8.

5 McKusick VA. Congenital deafness and Hirschsprung's disease. N Engl J Med 1973;288:691.

6 Klein D. Albinisme partiel (leucisme) accompagné de surdimutité d'osteomyodysplasie, de raideurs articulaires congenital multiples et d'autres malformations congenitales. Arch Klaus Stift Vererb Forsch 1947;22:336-42.

7 Bryan AL, Nigro JA, Counseller US. One hundred cases of congenital absence of the vagina. Surg Gynecol Obstet 1949;88: 79-86.

Correspondence and requests for reprints to Professor R M Goodman, Department of Medical Genetics, Sheba Medical Center, Tel-Hashomer 52621, Israel. 